\title{
Economical aspects of Flyash Based Geopolymer Concrete Paver Block
}

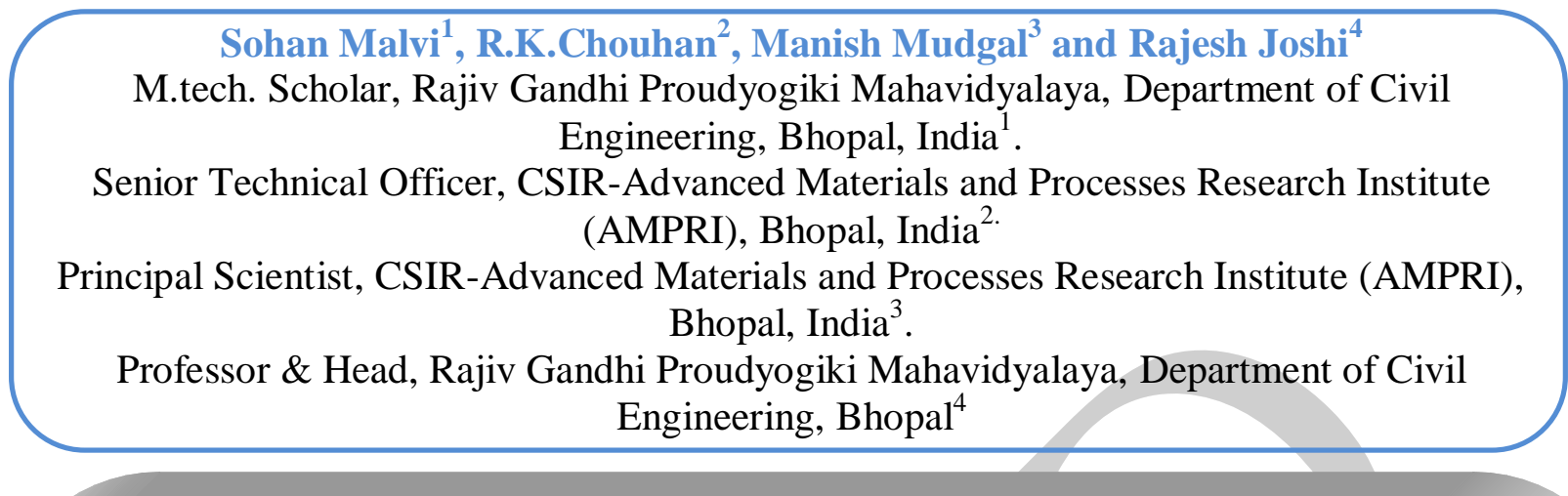

\section{ABSTRACT}

Green paver blocks is an ecofriendly method of making concrete paver block using geopolymer concrete. Paver blocks have been in use since thousands of years. Due to rapid infrastructure development cement concrete is the second most consumed commodity on earth today. Portland cement generates large amounts of carbon dioxide $\left(\mathrm{CO}_{2}\right)$ which is responsible for global warming since it is a greenhouse gas. Environmental responsibility has initiated research in sustainability, economical and ecofriendly methods for infrastructure development. The other great problem today is disposal of solid waste. Coal fired thermal power plants generate solid waste in the form of fly ash and pond ash. In this thesis I have design paver block by using Cement free geopolymer Concrete mixture of Design Mix M35 which is made of $4.75 \mathrm{~mm}$ Aggregate, and Fine Aggregate and paver block is of dimension 60 $\mathrm{mm}$ thick cosmic paver block. In this process use the partial replacement of Cement with Fly Ash and water with alkaline activator solution and crushed sand (Dust) in 100\% percentage and Molarities with 6.25M and 9.50M. The Paver Block ovened curing is done for 2 days and as well as ambient curing process to find its compressive strength and flexural strength. The main objective of this thesis is to use waste products like fly ash for the production of Paver Block which will useful in construction.

Key words: Coarse Aggregate, Fine Aggregate, Class-F Fly Ash, Compressive Strength, Flexural Strength, Ecofriendly, Economical Paver Block

\section{INTRODUCTION}

The concept of using interlocking paver block is very old. The first time road using paver block was constructed in 5000 B.C. by the Minoans. About 2000 years ago, with the help of labour and military group the first time roman constructed pavement roads. It was probably World War II that led to the growth of concrete blocks as a paving material. Concrete block pavement (CBP) was introduced in The Netherlands in the early 1950s as a replacement for baked clay brick roads. Green paver blocks have got nothing to do with color, but are an ecofriendly method of making concrete paver block. Paver blocks made of different materials have been in use since thousands of years.

In 1960 German developed high efficiency machinery tools for the construction of interlocking paver block. Manufacturing technology quickly followed by countries like South Africa New Zealand, Australia, Europe and England in the $1970^{\text {ee }}$ s. Due to rapid 
infrastructure development taking place, today Portland cement concrete is the second most consumed commodity on earth. Manufacture of ordinary Portland cement generates large amounts of carbon dioxide $\left(\mathrm{CO}_{2}\right)$ which is then released into the atmosphere. About $900 \mathrm{~kg}$ of $\mathrm{CO}_{2}$ is released for every ton of OPC manufactured [1]. $\mathrm{CO}_{2}$ is a major greenhouse gas which is responsible for global warming. As of 2010 the world production of OPC was 3300 million tons accounting for 5\% of global man-made carbon emissions. which has initiated research in sustainability and eco-friendly methods for infrastructure development. The other great problem today is disposal of solid waste. Coal fired thermal power plants generate solid waste in the form of fly ash and pond ash. Disposal of these wastes is a major engineering challenge with more stringent environmental laws. Today research has combined sustainability with waste management leading to a wonderful product called Geopolymer concrete. In 1978, a French scientist Joseph Davidovits developed a binder called Geopolymer by polymerization of source materials rich in silicon and aluminium with alkaline solutions [4]. Most commonly used source materials are fly ash and blast furnace slag. Geopolymer made of waste materials like fly ash have smaller carbon footprint compared to OPC [5]. According to Davidovits Geopolymer technology was used by Egyptians to build pyramids [6]. Modern day geopolymers are mostly made from low calcium fly ash activated by alkaline solutions $(\mathrm{NaOH}$ or $\mathrm{KOH})$ to liberate $\mathrm{Si}$ and $\mathrm{Al}$ with an additional source of silica (usually sodium silicate or potassium silicate). These are thermally activated along with aggregates to obtain geopolymer concrete. Water is not involved in chemical reaction of geopolymer concrete and is expelled during curing where as in ordinary Portland cement concrete, water is necessary for hydration to occur.

\section{GEOPOLYMER}

Geopolymers were $1^{\text {st }}$ developed by Joseph Davidovits in 1978 and named as "soil cement". They are produced at a temperature lower than required in manufacture of cement. Geopolymers are new group of building materials that has potential to transform the building products industries. Davidovits claims that the Egyptian Pyramids were built by casting geopolymer on site. He also reported that this material has excellent mechanical properties, does not dissolve in acidic solutions, and does not generate any deleterious alkali-aggregate reaction even in the presence of high alkalinity.

Geopolymers are a class of inorganic polymers formed by the reaction between an alkali and an aluminosilicate source. These materials have an amorphous 3-dimensional structure that gives geopolymers properties which make them an ideal substitute for Ordinary Portland Cement (OPC). Variations in the ratio of aluminium to silicon, and alkali to silicon, produce geopolymers with different physical and mechanical properties. It is an emerging class of cementitious material that utilizes 'fly ash', one of the most abundant industrial byproducts on earth. Ever since the introduction of geo polymer binders, it has generated a lot of interest among engineers as well as in the field of chemistry. In the past few decades, it has emerged as one of the possible alternative to cement binders.

\section{POLYMERIZATION OF THE GEOPOLYMERS}

Fly ash can be converted to a binding material by activating with alkaline solution [7]. It is observed that higher concentration of sodium hydroxide and high ratio of sodium silicate to sodium hydroxide liquid by mass results in higher compressive strength [8]. The strength of the geopolymer concrete decreases with the increase in ratio of water to geopolymer solids by mass [9]. Increase in curing temperature increases the compressive strength. It was found that 24 hours of steam curing at 60 to $80^{\circ} \mathrm{C}$ provided enough energy to aid geopolymerization 
[10]. Geopolymer concrete has excellent resistance to chemical attack and is an ideal option for use in aggressive environments [11].

Although the term 'geopolymer' is generically used to describe the amorphous to crystalline reaction products from synthesis of alkali aluminosilicates upon reaction with alkali hydroxide/alkali silicate solution, geopolymeric gels and composites are also commonly referred to as 'low-temperature aluminosilicate glass' [12], 'alkali-activated cement' [13], 'geo-cement' [14], 'alkali-bonded ceramic' [15], 'inorganic polymer concrete' [16], and 'hydroceramic' [17]. Despite this variety of nomenclature, these terms all describe materials synthesized utilizing the same chemistry, which can be described as a complex system of coupled alkali mediated dissolution and precipitation reactions in an aqueous reaction substrate.

Alkali-activation of blast-furnace slag has been used as an alternative means of cement production for over 65 years [18, 19], and slags are often used as a component of geopolymeric systems.

Typical image illustrating the microstructures of geopolymers synthesized from metakaolin and Class $\mathrm{F}$ fly ash is presented in fig 1 . and the Process showing geopolymers synthesized from metakaolin and class $\mathrm{F}$ ash in fig 2.

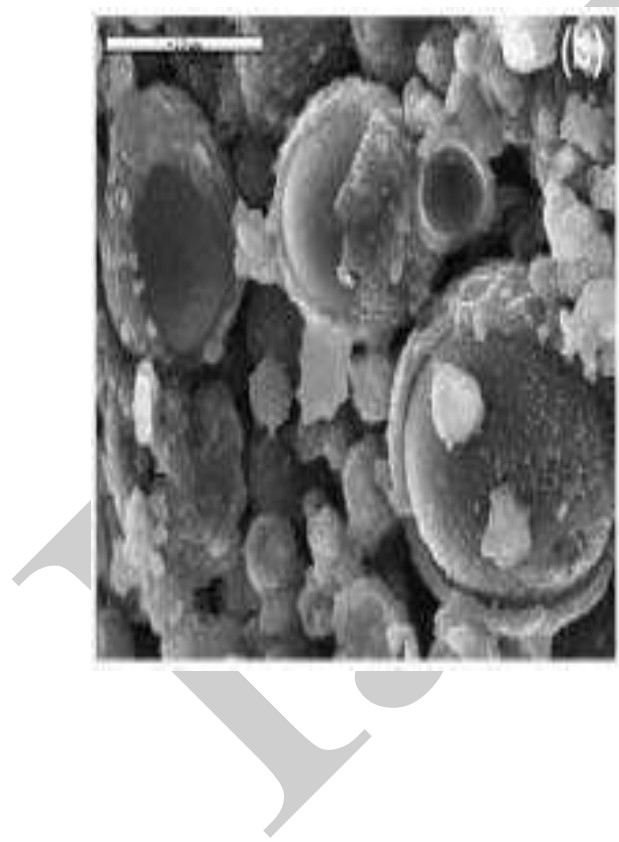

Fig 1. Microstructures of geopolymers synthesized synthesized from metakaolin and class $\mathrm{F}$ ash

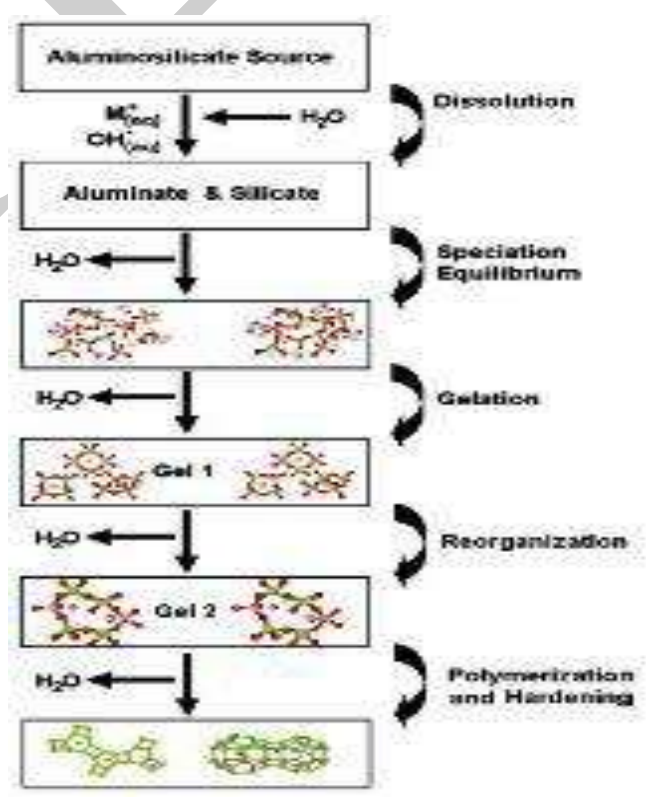

Fig 2. Process showing geopolymers from metakaolin and class $\mathrm{F}$ ash

This geosynthesis involves the chemical reaction of geopolymeric precursors such as aluminosilicate oxides with alkali polysilicates yielding polymeric $\mathrm{Si}-\mathrm{O}-\mathrm{Al}$ bonds as shown in (1). 
(A) $\mathrm{n}\left(\mathrm{Si}_{2} \mathrm{O}_{5}, \mathrm{Al}_{2} \mathrm{O}_{2}\right)+2 \mathrm{nSiO}_{2}+4 \mathrm{nH}_{2} \mathrm{O}+\mathrm{NaOH}$ or $\mathrm{KOH}$ $(\mathrm{OH})_{3}$

(Si-Al materials)
$-\mathrm{Na}^{+}, \mathrm{K}^{+}+\mathrm{n}(\mathrm{OH})_{3}-\mathrm{Si}_{-} \mathrm{O}_{-} \mathrm{Al}^{-}-\mathrm{O}-\mathrm{Si}-$

$(\mathrm{OH})_{2}$

(Geopolymer precursor) (Equation 1)

(B) $+4 \mathrm{H}_{2} \mathrm{O}$<smiles>O[Hg]O[AsH2]O[SiH2]O[AlH]O[SiH](O)O</smiles>

$(\mathrm{OH})_{2}$

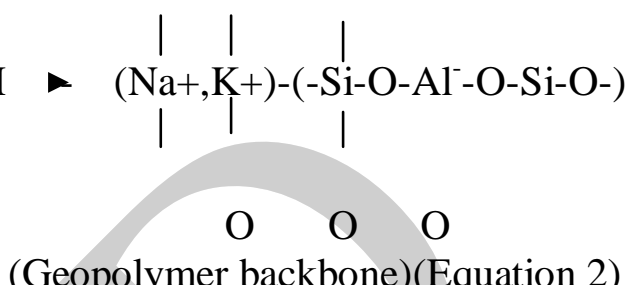

(Geopolymer backbone)(Equation 2)

.Eq as (A) and (B) (Panias.D and Giannopoulou.I 2004)

Gourley and Johnson have developed geopolymer precast concrete products for commercial scale. These include sewer pipes, railway sleepers and wall panels [20]. Precast reinforced geopolymer concrete culverts developed showed promising results on a commercial scale [21]. Geopolymer concrete can be effectively used as a substitute for OPC in precast concrete products. Geopolymer concrete is a feasible option for waste stabilization [22]. Several studies have been conducted across the world for effective use of geopolymer in various construction and infrastructure elements; this paper reports on the use of geopolymer concrete in precast concrete paver blocks and compares the performance with the commercial available OPC paver blocks of the same mix proportions.

The superior properties of geopolymer concrete, based on Prof. B.V. Rangan and Hardijito, are

a. Sets at room temperature

b. Nontoxic, bleed free

c. Long working life before stiffening

d. Impermeable

e. Higher resistance to heat and resist all inorganic solvents

f. Higher compressive strength

Compressive strength of geopolymer is very high

Compared to the ordinary Portland cement concrete. Geopolymer has also showed very high early strength hence it is used in the precast industries. Geopolymer Concrete showed good workability as of the Portland cement concrete.

Despite the many advantages the limitations are as follows:

a. Bringing the base material fly ash to the required location

b. High cost for the alkaline solution

c. Safety risk associated with the high alkalinity of the activating solution

d. Practical difficulties in applying steam curing/ high temperature curing process. [23]

Considerable research is ongoing to develop geopolymer systems that address these technical hurdles. 


\section{FLY ASH}

In this study, low calcium fly ash (Class F) from Thermal Power Plant, Sarni (Madhya Pradesh) as shown in Fig 1(a) was used as the source material. The fly ash particles are spherical, and grey in colour. The fly ash was characterized as Class F (conforming to IS 3812(Part-1):2013. The typical chemical composition and physical properties of fly ash are given in Table 1 and Table 2 respectively.

\begin{tabular}{|c|c|c|c|}
\hline \multicolumn{2}{|c|}{$\begin{array}{l}\text { Table } 1 \text { Chemical Composition of Fly } \\
\text { Ash }\end{array}$} & \multicolumn{2}{|c|}{ Table 2 Physical Properties of Fly Ash } \\
\hline \multirow[t]{3}{*}{ Compounds } & Mass & \multirow{12}{*}{$\begin{array}{l}\mathrm{pH} \\
\text { Specific Gravity } \\
\text { Blaine fineness } \\
\end{array}$} & \\
\hline & percentage & & 8.6 \\
\hline & $(\%)$ & & 2.1 \\
\hline $\mathrm{SiO}_{2}$ & 64.2 & & $360 \mathrm{~m}^{2} / \mathrm{kg}$ \\
\hline $\mathrm{Al}_{2} \mathrm{O}_{3}$ & 28.2 & & \\
\hline $\mathrm{Fe}_{2} \mathrm{O}_{3}$ & 3.70 & & \\
\hline $\mathrm{Na}_{2} \mathrm{O}$ & 0.17 & & \\
\hline $\mathrm{MgO}$ & 0.46 & & \\
\hline $\mathrm{CaO}$ & 0.06 & & \\
\hline $\mathrm{K}_{2} \mathrm{O}$ & 1.34 & & \\
\hline LOI* & 1.79 & & \\
\hline \multicolumn{2}{|c|}{$\begin{array}{l}* \text { LOI- Loss on ignition } \\
\text { About } 75 \% \text { of particles were finer than } 45 \\
\text { micron having specific gravity of } 2.1 \text { and } \\
\text { Blaine's specific surface area of fly ash } \\
\text { was } 360 \mathrm{~m}^{2} / \mathrm{kg} \text {. The pH of the fly ash used } \\
\text { was } 8.6 \text {. }\end{array}$} & & \\
\hline
\end{tabular}

FINE AGGREGATE (SAND)

Naturally locally available river sand was used as fine aggregate. Material passing $4.75 \mathrm{~mm}$ sieve and retained on $75 \mu \mathrm{m}$ sieve was used. The fineness modulus was 3.40 and specific gravity was 2.67 . Water absorption was $1.68 \%$. Fig. 3(b)

\section{COARSE AGGREGATE (STONE CHIPS)}

Crushed stone from granite was used as course aggregate. Material passing $10 \mathrm{~mm}$ sieve and retained on $4.75 \mathrm{~mm}$ were used. Specific gravity was 2.7 with bulk density of $1980 \mathrm{~kg} / \mathrm{m} 3$. They were free from deleterious matter confirming to IS 383-1970. Fig 3(c)

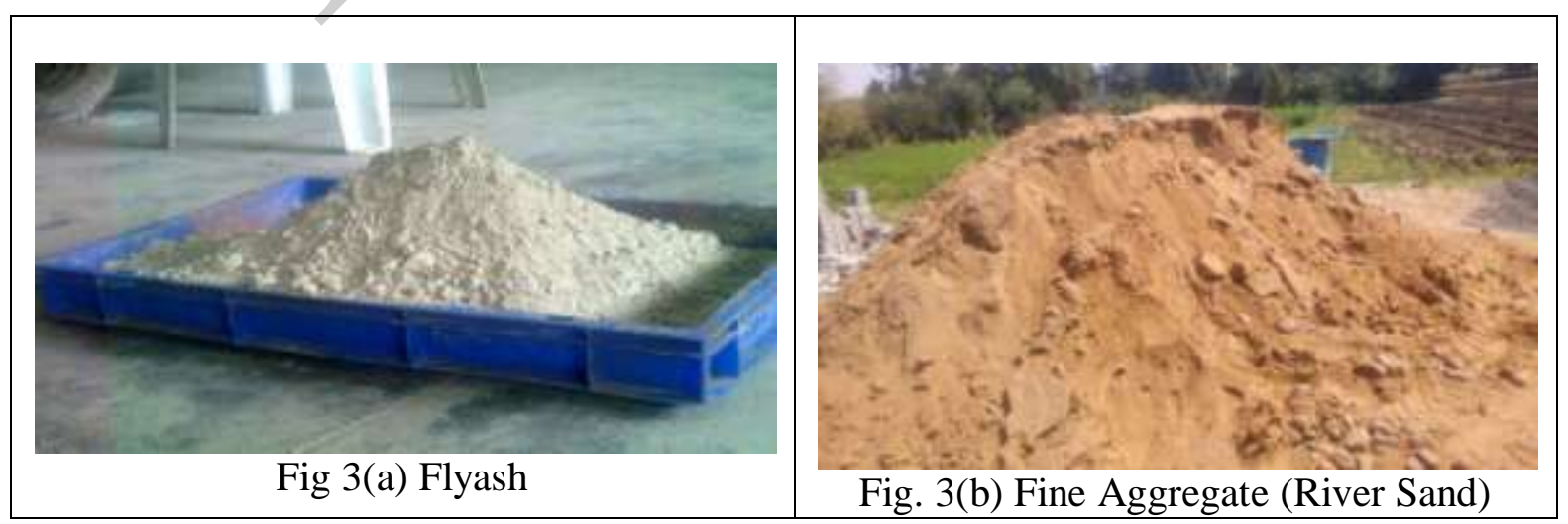




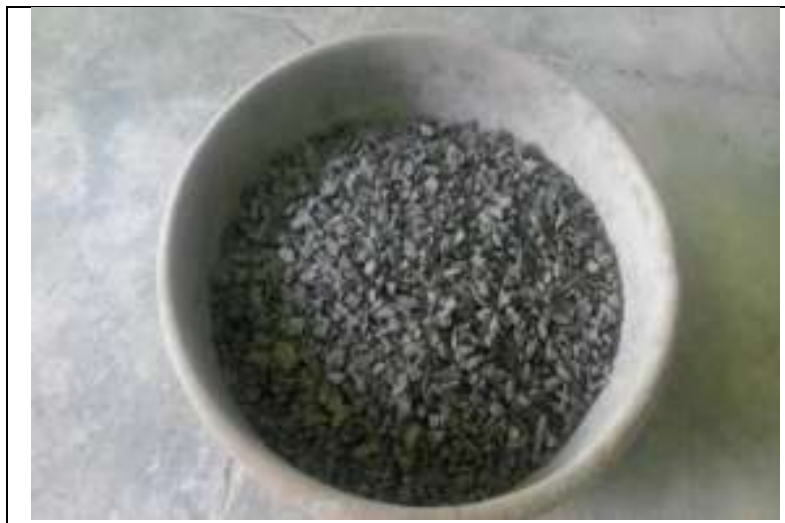

Fig. 3(c) Coarse Aggregate (stone chips)

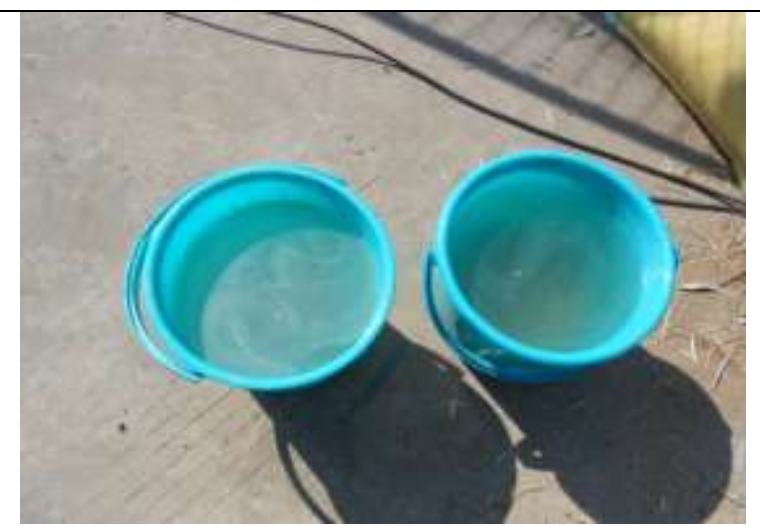

Fig. 3(d) Alkaline Activator

\section{PROPORTIONS}

The alkaline activator is prepared at least one hour prior to cast as shown in Fig 3(d). Firstly, the Sodium hydroxide $(\mathrm{NaOH})$ solution is prepared for the required molarity and then it is mixed with Sodium silicate $\left(\mathrm{Na}_{2} \mathrm{SiO}_{3}\right)$ in different proportion. The samples were prepared for $6.25 \mathrm{M}$ and $9.50 \mathrm{M}$. (Where, $\mathrm{M}-$ molarities). For e.g. $6.25 \mathrm{M}$ means, concentration of $\mathrm{NaOH}$ in one litre of water is $6.25 \times 40=250 \mathrm{gm}$, so for 5.4 litre of water $1.350 \mathrm{~kg}$ of $\mathrm{NaOH}$ is used to get required molarity (where 40 is the molecular weight of $\mathrm{NaOH}$ ). Mix proportions for various samples are illustrated in Table 3.

Table 3 Mix proportions of materials used in experiment

\begin{tabular}{|c|c|c|c|c|c|c|c|c|}
\hline Sample & $\begin{array}{c}\text { Fly } \\
\mathbf{a s h} \\
(\mathbf{k g})\end{array}$ & $\begin{array}{c}\text { Sand } \\
(\mathbf{k g})\end{array}$ & $\begin{array}{c}\text { Stone } \\
\text { Chips } \\
(\mathbf{k g})\end{array}$ & Molarity & $\begin{array}{c}\text { Water } \\
\text { (ltr) }\end{array}$ & $\begin{array}{c}\text { SMS/NaOH } \\
\text { (Ratio) }\end{array}$ & $\begin{array}{c}\text { Sand to } \\
\text { Fly ash } \\
\text { ratio }\end{array}$ & $\begin{array}{c}\text { Activator } \\
\text { to fly ash } \\
\text { ratio }\end{array}$ \\
\hline Mix-1 & 18.0 & 30.0 & 6.0 & 6.25 & 5.400 & 1.0 & 1.6 & 1.8 \\
\hline Mix-2 & 18.0 & 30.0 & 6.0 & 9.50 & 5.400 & 1.0 & 1.6 & 1.8 \\
\hline
\end{tabular}

PROCEDURE

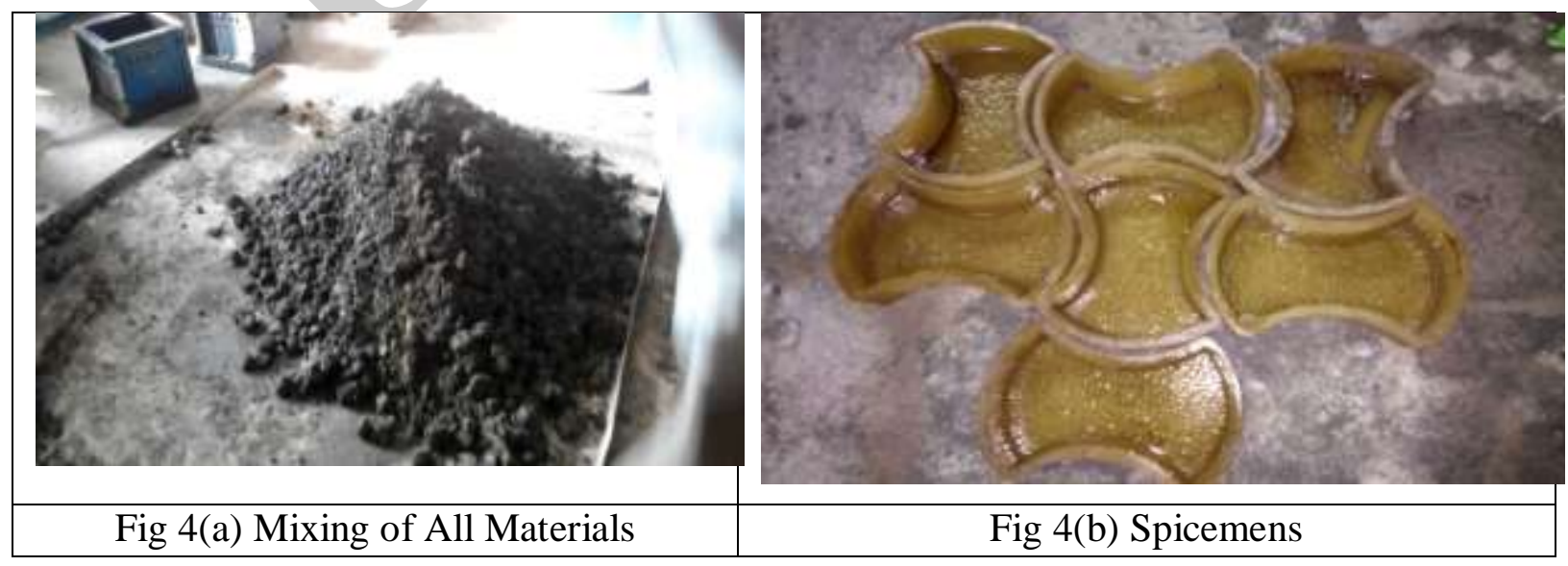



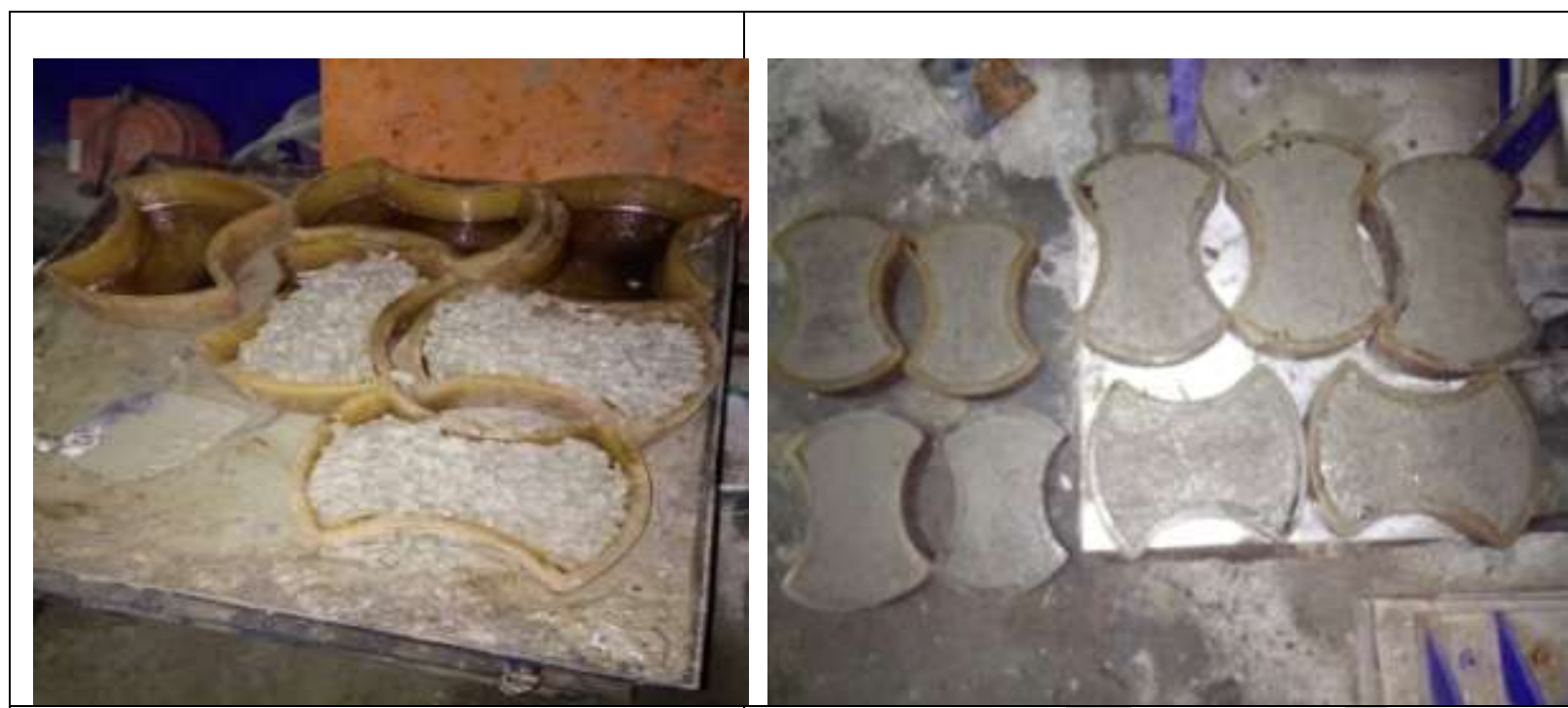

Fig 4(c) Casting a paver blocks on vibrating table

Fig 4(d) Casted Paver blocks

\section{CASTING \& CURING}

The fly ash and sand are first dry mixed for three minutes and then alkaline solution of different molarity i.e. $6.25 \mathrm{M}$ and $9.50 \mathrm{M}$ is added in specified proportion for about 10 minutes so that the homogeneous mixture is obtained. The concrete paver blocks samples have been casted in Silicon paver blocks moulds of size $250 \mathrm{mmX} 250 \mathrm{mmX} 50 \mathrm{~mm}$. The fresh geopolymer concrete paver blocks is then filled in mould immediately after mixing in two layers and hand compacted to avoid the air bubbles and then vibrated for $15 \mathrm{~s}$ on a vibrating table. After casting, geopolymer concrete paver blocks samples are left to room temperature for one hour under atmospheric pressure and uncontrolled humidity conditions and are cured in an oven at $60^{\circ} \mathrm{C}$ for duration $48 \mathrm{hrs}$. At the end of curing period the oven is turned off and the specimens is allowed to cool down inside the oven to room temperature. The samples are then removed from the mould and they are left to ambient curing (drying) at room temperature before being tested for compressive strength.

\section{RESULTS}

The compressive strength values of fly ash based geopolymer concrete paver blocks samples having different molar concentration of $6.25 \mathrm{M}$ and $9.50 \mathrm{M}$ are given in Table 4,5 and 6.

Table 4 Compressive strength of geopolymer concrete paver blocks after 3, 7, 14, 28 days after $48 \mathrm{hrs}$ curing at $60^{\circ} \mathrm{C}$.

\begin{tabular}{|c|c|c|}
\hline \multirow{2}{|c|}{ Molarity $\rightarrow$} & $\mathbf{6 . 2 5 M}$ & $\mathbf{9 . 5 0 M}$ \\
\hline Days $\downarrow$ & \multicolumn{2}{|c|}{ Avg Compressive strength (N/mm $\mathbf{m}^{\mathbf{}}$ ) } \\
\hline 3 & 15.9 & 20.8 \\
\hline 7 & 25.7 & 27.6 \\
\hline 14 & 35.4 & 34.4 \\
\hline 28 & 39.8 & 48.2 \\
\hline
\end{tabular}


The minimum compressive strength was found as 15.9 and $20.8 \mathrm{~N} / \mathrm{mm}^{2}$ after 3 days for $6.25 \mathrm{M}$ and $9.50 \mathrm{M}$. Geopolymer concrete paver blocks samples oven cured at $48 \mathrm{hrs}$ samples. The maximum compressive strength was found to be 39.8 and $48.2 \mathrm{~N} / \mathrm{mm}^{2}$ after 28 days for $6.25 \mathrm{M}$ and $9.50 \mathrm{M}$ geopolymer concrete paver blocks samples. The compressive strengths of 6.25 and $9.50 \mathrm{M}$ geopolymer concrete paver blocks samples increased with curing condition as can be seen graphically in Fig 5.

The variation in Compressive strength increment with molarity of $\mathrm{NaOH}(6.25 \mathrm{M}$ $\& 9.50 \mathrm{M})$ for the geopolymer concrete paver blocks specimens is shown in Figure 2. The compressive strength obtained was in the range of $15 \mathrm{MPa}$ to $50 \mathrm{MPa}$. Higher concentration of sodium hydroxide solution yielded higher compressive strength. The Mix 1 (6.25M) gives the minimum compressive strength and the Mix 2 (9.50M) gives the maximum compressive strength among other geopolymer concrete paver blocks samples.

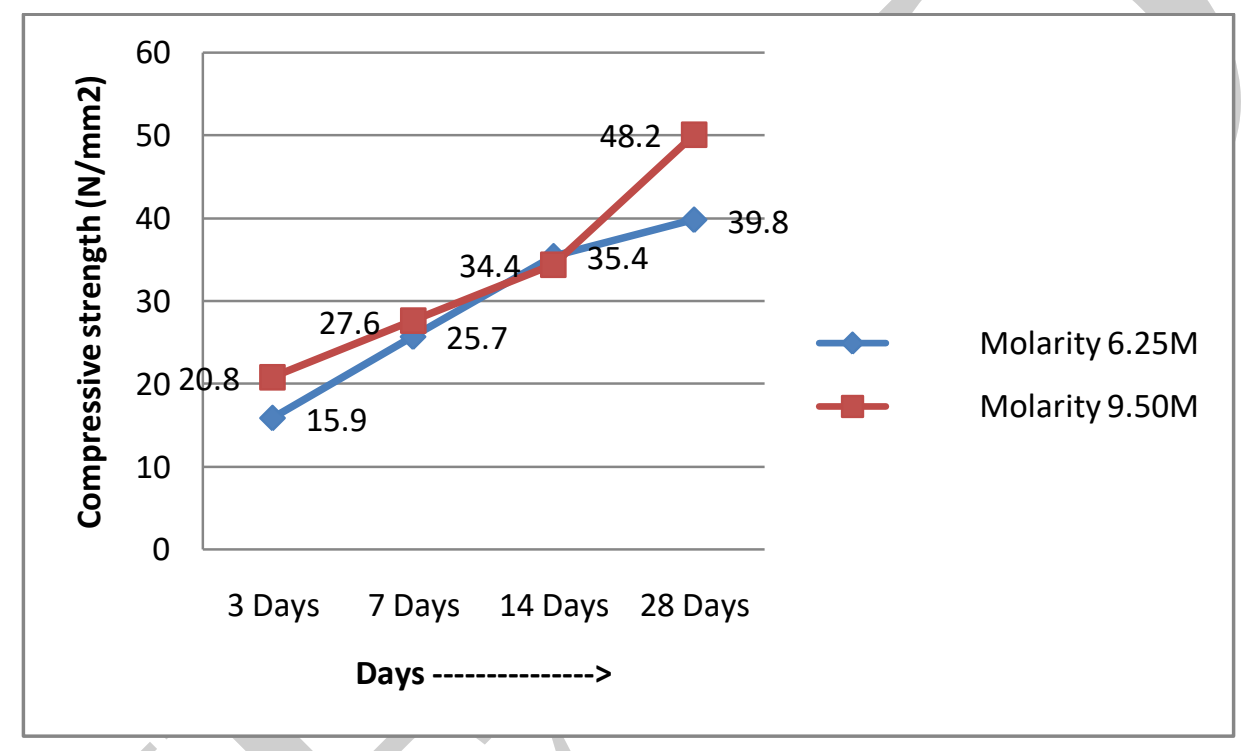

Fig. 5 Compressive strength values of geopolymer paver blocks samples.

The compressive strengths of all the specimens increased with curing duration. the thermal curing significantly affected the compressive strengths. The strength increased about 2 times at 3 days for $9.50 \mathrm{M}$ geopolymer paver blocks samples as compared with $6.25 \mathrm{M}$ geopolymer paver blocks samples.

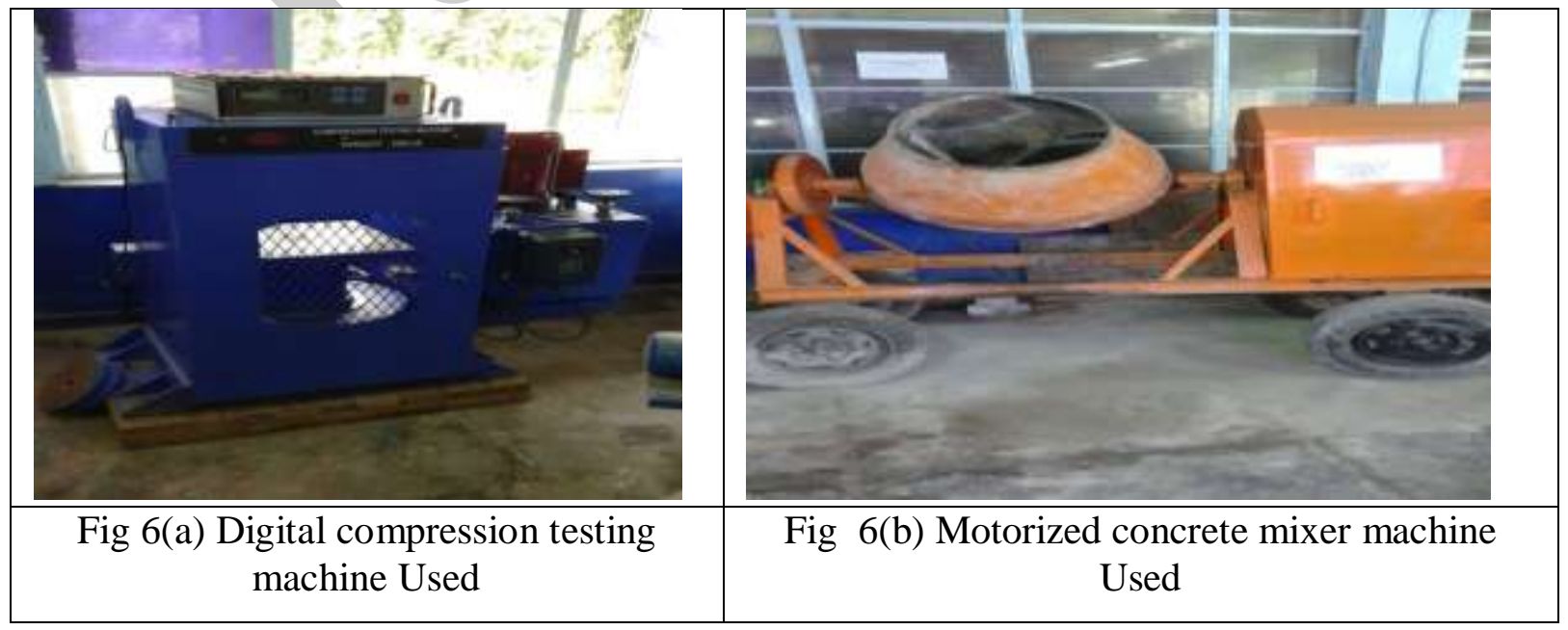




\section{DICUSSIONS}

The results showed that the compressive strength of the geopolymer concrete paver blocks samples increased with increase in curing condition and molarity. The effect of curing condition on the compressive strength was found to be more significant for curing times such as 48 hours. Longer curing time improved the polymerization process resulting in higher compressive strength. This might be due to relatively fast chemical reaction process in the geopolymer concrete paver blocks.

A Compression testing Machine (CTM) model number HLM592.401 HEICO Ltd. Capacity $3000 \mathrm{kN}$, High capacity steel load frame with different sizes of platens arrangements, Ram travel 50mm-70mm, Horizontal Clearance $350 \mathrm{~mm}-400 \mathrm{~mm}$, Vertical Clearance $400 \mathrm{~mm}-500 \mathrm{~mm}$, India was used to test the compressive strength of concrete paver blocks and cubes. A Motorized Concrete mixer machine Capacity-100liters, TypeMotorized, electrically operated, Tilt Capacity-1.5 to $2.0 \mathrm{Cu}$.Ft., Drum Volume-2-3H.P., Suitable for operation on 220/230 volts A.C. Single phase.

Compressive strength for the concrete paver blocks were tested by applying load of 9.0 $\mathrm{KN} / \mathrm{sec}$. The paver blocks were tested in compressive testing machine to determine their compressive strength. Table 4 shows the compressive strength of the cube specimens at 3, 7, 14, 28 days age of concrete paver blocks.

The variations in Compressive strength increment with molarity of $\mathrm{NaOH}(6.25 \mathrm{M}$, $9.50 \mathrm{M}$ ) for the geopolymer concrete paver blocks specimens is shown in Figure 2. This is due to increase in release of aluminate and silicate species from amorphous silico aluminous phases of the fly ash. The compressive strength obtained was in the range of $15 \mathrm{MPa}$ to $50 \mathrm{MPa}$. Higher concentration of sodium hydroxide solution yielded higher compressive strength. The Mix $2(9.50 \mathrm{M})$ gives the maximum compressive strength among other samples. It is comparable with 7 days compressive strength of Portland cement; 33 grade-specification.

\section{CONCLUSIONS}

Geopolymer concrete paver blocks which is produced by the inorganic polymeric reaction of fly ash and alkali activated solution is used for this experiment. Geopolymer are new materials which have various application fields. There are many parameters affecting the geopolymerisation. The study of influence of curing condition and molarity on compressive strength of geopolymer concrete paver blocks have revealed as listed below:

- It has been found that as the molarity increases, compressive strength increases. This is due to greater dissolution of source material.

- The compressive strength values indicated that the curing conditions influenced the physical properties of fly ash based geopolymer concrete paver blocks samples. As the curing duration increased, the compressive strengths increased. This may attributed to higher degree of geopolymerization.

- The geopolymer concrete paver blocks mixes were produced easily using conventional equipment similar to those used for production of conventional cement concrete paver blocks.

The Geopolymer binder may be treated as future environment friendly alternative to Portland cement and Economical aspects also. Thus the geopolymer binders developed from Class $\mathrm{F}$ fly ash can be used as a substitute to Ordinary Portland cement.

\section{ACKNOWLEDGMENT}

Authors are thankful to Director CSIR-AMPRI, Bhopal for providing facilities and guidance in carrying out the R\&D studies. 


\section{REFERENCES}

[1] Ritesh Mall, Sharda Sharma "Studies of the properties of Paver Block using Fly ash" International Journal for Scientific Research \& Development (IJSRD) Vol.2, Issue 10, pp. 59-64, 2014.

[2] Rismy Muhammed and Deepthy Varkey "An Experimental on Flyash based Geopolymer Pavement Blocks with Polypropylene fibre" International Journal of Innovative Science, Engineering \& Technology (IJISET), Vol.3 Issue 8, pp. 548-553, 2016.

[3] J Davidovits, Geopolymer Chemistry \& Applications, Institute Geopolymer, France, 2008.

[4] Alam J. and Akhtar M.N. "Fly autilization in different sectors in Indian scenario." International Journal of emerging trends in Engineering and Development, Vol.1, No.1, pp.1-14, 2011.

[5] Davidovits. J., Geopolymers: inorganic polymeric new materials, Journal of thermal analysis, 37, pp 1633-1656, 1991.

[6] IS: 3812:1981, Specification for fly ash for use as pozzolana and admixtures 3812(part1): 2003.

[7] Rajamane N.P, Sabitha D., Studies on geo-polymer mortars using fly ash and blast furnace slag powder, International Congress on fly ash, Fly ash India, Chapter 6, pp 0019, pp 1-7, 2005.

[8] Davidovits Joseph, "30 years of successes and failures in Geopolymer Applications in Geopolymer Applications. Market Trends and Potential Breakthroughs." Geopolymer Conference, October 28-29, 2002, Melbourne, Australia, 2002.

[9] Palomo et al, "Alkali Activated fly ashes A cement for the future."Cement and Concrete Research, pp.1323-1329, 1999.

[10] Panis.D and Giannopoulou.I, "Conference: 1st International Conference on Advances in Mineral Resources Management and Environmental Geotechnology, AMIREG, pp.407412, 2004.

[11] Swanepoel,J.C. and C.A. Strydon, "Utilization of fly ash in a geopolymeric material." Applied geochemistry, Vol.17, No.8, pp.1143-1148, 2002.

[12] Bhosale. M. A., and Shinde. N.N, "Geopolymer Concrete by Using Fly Ash in Construction." ISOR Journal of Mechanical and Civil Engineering, Vol.1, No.3, pp. 2530, 2012.

[13] Hardijito Djwantoro, Wallah .E Stennie, Sumajouw .J M. Dody and Rangan Vijaya B, "Factors Influencing the Compressive Strength of Fly Ash Based Geopolymer Concrete." Civil Engineering Dimension Vol.6, No.2, pp. 88-93, 2005.

[14] R. Malathy and T. Manjupriya "Experimental investigation on utilization of EOF steel slag as aggregate Paver Blocks" International Journal of Engineering Research and Technology (IJERT) ISSN No.2348-6821 , pp. 122-124.

[15] Aaron Darius Vaz and Donal Nixon D’Souza “Geopolymer Paver Blocks” Proceeding of Int. Conf. on Advances in Civil Engineering (ACEE) 2012.

[16] Som nath Sachdeva, Vanita Aggarwal "High Volume Fly ash Concrete for Paver Blocks" International Journal of Civil, Environmental, Structural Construction and Architectural Engineering Vol. 8 No.3 pp. 242-248, 2014.

[17] Prof. M.A.Bhosale and Prof. N.N.Shinde "Geopolymer Concrete by Using Flyash in Construction" IOSR Journal of Mechanical and Civil Enineering (IOSRJOMC) Vol 1, Issue 3, pp. 25-30, 2012. 